\title{
ROZPORZĄDZENIE REACH W ŚWIETLE ZASADY OSTROŻNOŚCI
}

\section{REACH REGULATION IN THE LIGHT OF PRECAUTIONARY PRINCIPLE}

\section{STRESZCZENIE}

Artykuł dotyczy rozporządzenia REACH stanowiącego odpowiedź na coraz szerszą obecność chemikaliów w naszym życiu oraz ich wpływu na zdrowie i środowisko człowieka. Rozporządzenie REACH jest przedstawione w świetle zasady przezorności w celu udzielenia odpowiedzi na pytanie, do jakiego stopnia rozporządzenie, którego rozwiązania $\mathrm{w}$ zamierzeniu jego twórców miały stanowić wyraz zasady $\mathrm{w}$ rzeczywistości to czynią. Zasada ta $\mathrm{w}$ odniesieniu do zarządzania chemikaliami stosowana jest wówczas, gdy pomimo istnienia wiarygodnych dowodów naukowych, co do szkodliwego wpływu substancji na zdrowie człowieka i środowisko naturalne wciąż nie ma na-

\footnotetext{
" Doktor nauk prawnych, Akademia Leona Koźmińskiego.
} 
ukowej pewności co do charakteru i wielkości szkód, które może ona potencjalnie wywołać. Bez wątpienia do elementów rozporządzenia, które zgodnie z założeniami jego twórców odzwierciedlają założenia koncepcji zalicza się przerzucenie odpowiedzialności za ocenę szkodliwości substancji z władz publicznych na producentów czy też wprowadzona przez rozporządzenie konieczność poszukiwanie rozwiązań alternatywnych, a także autoryzacja jako część procedury wdrażania rozporządzenia. Przezorność jest także środkiem służącym zarządzaniu ryzykiem - ma zastosowanie zawsze wówczas, gdy ryzyko osiąga nieakceptowany poziom. W literaturze przedmiotu wskazuje się jednak na wątpliwości co do realizacji przez rozporządzenie omawianej koncepcji. Tym, co wpływa na takie stanowisko, jest między innymi wątpliwość, kiedy podstawą działań podejmowanych zgodnie z rozporządzeniem powinna być przezorność.

\section{Słowa kluczowe}

Przezorność; rozporządzenie REACH; chemikalia; zarządzanie ryzykiem.

\section{ABSTRACT}

The paper concerns the REACH regulation as a response to broad presence of chemicals in our lives and their impact on human health and the environment. REACH is presented in the light of the precautionary principle in order to answer the question to what extent the regulation, whose solutions were intended to be an expression of the concept, really applies. The precautionary concept is used for the management of chemicals if, despite the existence of credible scientific evidence concerning the harmful effects of substances on human health and the environment, there is still no scientific certainty as to the nature and size of the damage that may be caused. There are elements of the regulation which reflect the precautionary concept including the shifting of responsibility for the assessing the harmfulness of a substance from public authorities to manufacturers or a measure according to which there is the need to search for alternative solutions, as well as the authorisation procedure. Precaution is also the measure of risk management - it always applies when the risk reaches unacceptable levels. However, in the literature there are some doubts concerning the realization of the concept by the REACH regulation. 
What affects the position is the doubt, when the precaution should be the basis of activities undertaken in accordance with the regulation.

\section{Keywords}

Precaution; REACH regulation; chemicals; risk management.

\section{WPROWADZENIE}

Waga problemu, jakim jest szkodliwe oddziaływanie substancji chemicznych na zdrowie i życie człowieka jest ogromna. W codziennym życiu nie zawsze bowiem uświadamiamy sobie fakt ich ciągłej obecności i takiego też oddziaływania. Obecności i szkodliwości niektórych z nich, tych najbardziej popularnych jesteśmy świadomi (jak np. DDT), charakteru pozostałych nie uświadamiamy sobie bądź też po prostu o nich nie wiemy. Warto jednak zdać sobie sprawę, że jesteśmy wciąż wystawieni na działanie substancji szkodliwych, które nie pozostają bez znaczenia dla naszego zdrowia i samopoczucia. Potrzeba regulacji rynku chemikaliów wynikała ze zmiany oceny wpływu tych substancji na ekosystem. Funkcjonujący przez długi czas pogląd dotyczący nieograniczonych możliwości przyswajania przez środowisko naturalne zanieczyszczeń, w tym przede wszystkim pochodzących od substancji toksycznych, stał się nieaktualny. Zrównoważony sposób wykorzystywania zasobów naturalnych jest więc nie tylko zagrożony poprzez ich szeroką eksploatację, lecz również z uwagi na nadmierną obecność substancji chemicznych, których ekosystemy nie są w stanie asymilować. Istotne jest również to, że przyczyną obecności substancji chemicznych, negatywnie wpływających na stan środowiska, są nie tylko podmioty wytwarzające je obecnie, lecz również te, które czyniły to dawniej. Skutki ich działalności są jednak wciąż odczuwalne - zarówno w środowisku, jak i przez człowieka ${ }^{2}$.

1 J. Lee, A. Brandt Pedersen, M. Thomson, Framework for combining REACH and national regulations to obtain equal protection levels of human health and the environment in different countries, Comparative study of Denmark and 
Istota problemu, jakim jest oddziaływanie substancji chemicznych jak również potrzeba działań służących zmniejszeniu ich negatywnego wpływu jest wciąż niedoceniana. Problemem jest przede wszystkim niezbadany zakres ich negatywnego wpływu na życie i zdrowie człowieka jak również na zasoby naturalne. Nie zbadano również ich przenikania. Obecność szkodliwych substancji, powodujących trwałe zanieczyszczenia organiczne zauważona została niedawno w rejonie Arktyki - a więc na obszarze, na którym nigdy nie były wytwarzane i stosowane. Oznacza to, że substancje chemiczne są niewidocznym zagrożeniem dla zasobów środowiskowych w wymiarze globalnym² ${ }^{2}$.

Szeroka obecność substancji chemicznych na wspólnym rynku, w tym tych szkodliwych spowodowała konieczność ujednolicenia uregulowań ich dotyczących.

\section{PRZYCZYNY WPROWADZENIA ROZPORZĄDZENIA REACH}

Rozporządzenie REACH w sprawie rejestracji, oceny, udzielania zwolnień i stosowanych ograniczeń w zakresie chemikaliów oraz tworzące Europejską Agencję Chemikaliów przyjęte zostało 18 grudnia 2006 r. przez Parlament Europejski i Radę Unii Europejskiej. Uchyliło ono dotychczas obowiązujące rozporządzenie Rady (EWG) 793/93 i rozporządzenie Komisji (WE) 1488/94, jak również dyrektywę Rady 76/769/EWG

Korea, „Journal of Environmental Management” 2013, nr 125, s. 106; J. Rockström, A safe operating space for humanity, „Nature” 2009, nr 461, s. 472-479; K. Bester, L. Scholes, C.S., Wahlberg, C., McArdell, Sources and mass flows of xenobiotics in urban water cycles - an overview on current knowledge and data gaps, „Water Air \& Soil Pollution” 2008, nr 8, s. 407-423.

2 A. Fromberg, M. Cleemann, L. Carlsen, Review on persistent organic pollutants in the environment of Greenland and Faroe Islands, "Chemosphere” 1999, nr 38, 3075-3093. 
i dyrektywy Komisji 91/155/EWG, 93/67/EWG, 93/105/WE i $2000 / 21 / \mathrm{WE}^{3}$.

Rozporządzenie zostało przyjęte na skutek propozycji zmian przedstawionych w Białej Księdze ${ }^{4}$. Zwolennikami wprowadzenia zmian były również państwa członkowskie (największy wpływ na kształt przyjętych rozwiązań miały propozycje złożone przez Szwecję, która zwróciła szczególną uwagę na kwestię ryzyka oraz problematykę realizacji koncepcji ostrożności $)^{5}$, przemysł oraz organizacje pozarządowe ${ }^{6}$. Dotychczas istniejące rozwiązanie ${ }^{7}$ - rozporządzenie dotyczące oceny ryzyka i kontroli substancji - uznawane było za nieskuteczne i czasochłonne w stosowaniu. Niechęć wobec istniejącej regulacji wzmagała także złożoność procedur i rozdrobnienie przepisów ${ }^{8}$.

Biała Księga określiła nowe rozwiązania w sprawie rynku chemikaliów. Uznano w niej, że podstawową rolę dla osiągnięcia wysokiego poziomu ochrony zdrowia ludzkiego i ochrony środowiska w kontekście regulacji obrotu chemikaliami w Unii Europejskiej odgrywa zasada przezorności zarówno w zapewnieniu bezpieczeństwa chemicznego obecnych, jak i przyszłych pokoleń. Przy czym zastosowanie jej nie powinno zakłócać funkcjonowania wspólnego rynku chemikaliów oraz unijnych reguł konkurencji. Zgodnie z Białą Księgą na zasadę przezorno-

3 Dz.Urz. UE L 396 z 30 grudnia 2006 r.

4 The White Paper on Strategy for a future chemicals Policy. COM (2001) 88 Final, Komisja Europejska, Bruksela, 27.2.2001, dostępne na: http://eur lex.europa.eu/LexUriServ/LexUriServ.do?uri=COM:2001:0088:FIN:EN:PDF; data wejścia 8.12.2013 r.

${ }^{5}$ D. Pesendorfer, EU environmental policy under pressure: chemicals policy change between antagonistic goals? „Environmental Politics” 2006, nr 15 (1), s. 95-114.

${ }^{6}$ T. Assmuth, M. Hildén, M. Craye, Beyond REACH: Roadblocks and shortcuts en route to integrated risk assessment and management of chemicals, „Science of the Total Environment” 2010, nr 408, s. 3954-3963.

7 Rozporządzenie Rady (EWG) nr 793/93 z dnia 23 marca 1993 r. w sprawie oceny $i$ kontroli ryzyk stwarzanych przez istniejące substancje, Dz.Urz. WE L 084, z 05.04. 1993, s. $1-75$.

8 T. Assmuth, M. Hildén, M. Craye, op. cit., s. 3955. 
ści należy powoływać się zawsze, gdy mamy do czynienia z niedopuszczalnym ryzykiem ${ }^{9}$.

W literaturze przedmiotu prace nad rozporządzeniem REACH traktowane są jako przykład największego oddziaływania lobbingu w historii prawodawstwa UE. Kampania podjęta przez producentów wyrobów chemicznych objęła państwa członkowskie UE jak również Japonię i Stany Zjednoczone - które w sposób szczególny ostrzegały przed konsekwencjami, jakie może wywołać przyjęcie rozporządzenia. Największe wątpliwości budził poziom ochrony zdrowia oraz realizacja zasady przezorności przez rozporządzenie ${ }^{10}$.

Podstawowym celem rozporządzenia REACH jest więc zapewnienie skutecznego funkcjonowania wspólnego rynku substancji chemicznych zapewniając równocześnie (obowiązek ten spoczywa na producencie), że chemikalia te nie będę stanowiły zagrożenia dla zdrowia i życia ludzkiego. Ponadto realizacja rozporządzenia REACH służyć powinna zwiększeniu konkurencyjności przemysłu chemicznego. Przez zwolenników rozporządzenia jest ono uważane również za jeden z czynników, wpływający na zwiększenie innowacji ze względu na istnienie spójnej podstawy prawnej - dotychczasowa złożoność regulacji nie pozwalała na osiągnięcie tego celu ${ }^{11}$. Jak zauważają C.J. van Leeuwen i T.G Vermeire ${ }^{12}$, celem rozporządzenia REACH jest również promocja alternatywnych metod oceny zagrożeń wywoływanych przez substancje chemiczne jak i zapewnienie swobodnego przepływu substancji $\mathrm{w}$ ramach wolnego rynku UE. Obszerność rozporządzenia REACH (850 stron) i wytycznych (3500 stron) ma służyć efektywnej realizacji jego założeń

9 The White Paper on Strategy for a future chemicals Policy. COM (2001) 88 Final, Komisja Europejska, Bruksela, 27.2.2001, dostępne na: http://eur lex.europa.eu/LexUriServ/LexUriServ.do?uri=COM:2001:0088:FIN:EN:PDF; data wejścia 8.12.2013.

10 S. Loewenberg, US chemical companies leave their mark on EU law, „Lancet” 2006, nr 367 (9510), s. 556-557, podaję za: T. Assmuth, M. Hildén, M. Craye, Beyond REACH..., op. cit., s. 3955.

11 T. Assmuth, M. Hildén, M. Craye, op. cit., s. 3955.

12 C. J. van Leeuwen, T. G. Vermeire (red.), Risk Assessment of Chemicals: An Introduction, Springer 2007, s. 511-551. 
przez przemysł chemiczny w tym przez dostarczanie dokładnych informacji na temat wytwarzanych substancji ${ }^{13}$.

\section{CEL I PRZEDMIOT ROZPORZĄDZENIA}

Rozporządzenie REACH obowiązuje w państwach członkowskich od 1 stycznia 2007 r. W momencie jego przyjęcia było uznawane za najsurowsze $\mathrm{z}$ dotąd przyjętych $\mathrm{w}$ środowisku międzynarodowym uregulowań dotyczących produktów chemicznych ${ }^{14}$. System REACH jest akronimem słów Registration, Evaluation, Authorisation of Chemicals a więc - Rejestracja, Ocena, Udzielanie Zezwoleń w zakresie Chemikaliów, które stanowią niejako jego filary.

Celem rozporządzenia, który został określony w jego art. 1 przede wszystkim, zapewnienie wysokiego poziomu ochrony zdrowia i środowiska, w tym propagowanie alternatywnych metod oceny zagrożeń stwarzanych przez substancje, jak również zapewnienie swobodnego obrotu substancjami $\mathrm{w}$ ich postaci własnej, jako składników preparatów lub w wyrobach na rynku wewnętrznym przy jednoczesnym wsparciu konkurencyjności i innowacyjności ${ }^{15}$. Rozporządzenie powinno również, zgodnie z jego preambułą, propagować rozwój alternatywnych metod oceny zagrożeń stwarzanych przez substancje. Rozporządzenie REACH wprowadzając jednakowe rozwiązania dla substancji chemicznych sprawia, że obrót nimi dokonuje się na jednolitych zasadach na obszarze wspólnego rynku. Równocześnie jednak należy podkreślić, że rozporządzenie REACH jest środkiem, który uwzględnia różnice terytorialne w zakresie prowadzonej działalności przemysłowej - zarówno obecnie, jak i w przeszłości i skutki, jakie działalność ta wywołuje bądź wywoływała w środowisku naturalnym. Stężenia wartości substancji che-

13 Ibidem.

14 J. Lee, A. Brandt Pedersen, M. Thomsen, op. cit., 105-116.

15 Art. 1 ust. 1 rozporządzenia REACH. 
micznych w środowisku powinny być osiągane przy zastosowaniu zasady ostrożności ${ }^{16}$.

Przedmiotem rozporządzenia REACH są wszystkie chemikalia za wyjątkiem tych, które normowane są przez odrębne przepisy prawa unijnego a tym samym wyłączone spod działania rozporządzenia. Przykładem mogą być tu środki ochrony roślin, kosmetyki, dodatki do żywności. Nowe rozporządzenie dotyczy zarówno substancji wprowadzonych na rynek po 1981 r., których dotąd dotyczył obowiązek oceny jak i tzw. starych substancji, a więc tych, które na rynku chemikaliów istniały już w latach 1971-1981.

Rozporządzenie REACH wprowadza nową filozofię w odniesieniu do podmiotów odpowiedzialnych za dostarczenie informacji na temat substancji wprowadzonych do obrotu. Jak dotąd podmiotami odpowiedzialnymi za ocenę ryzyka substancji były organy władzy publicznej, natomiast obowiązek dostarczenia informacji dotyczących właściwości substancji spoczywał na producentach oraz importerach substancji chemicznych. Rozporządzenie REACH przenosi zaś odpowiedzialność za zapewnienie bezpieczeństwa substancji chemicznych będących na rynku z organów władzy publicznej na przedsiębiorców. Opiera się więc na regule "no data - no marketing" ${ }^{17}$.

Znaczenie regulacji REACH jest istotne również z uwagi na zakres jego oddziaływania. Przedsiębiorcy spoza Unii Europejskiej, którzy chcą wprowadzić swoje produkty, objęte rozporządzeniem REACH na rynek unijny muszą spełniać przesłanki określone przez rozporządzenie. Można więc stwierdzić, że skuteczność rozporządzenia wychodzi poza granice Unii. REACH reguluje więc przepływ towarów - substancji chemicznych w Unii Europejskiej i poza nią (w odniesieniu do producentów eksportujących ten substancje na rynek unijny). 


\section{MIEJSCE ROZPORZĄDZENIA REACH W POLITYCE OCHRONY ŚRODOWISKA UE}

Rozporządzenie REACH jest środkiem będącym wyrazem polityki Unii Europejskiej w sferze ochrony środowiska. Oznacza to, że realizuje w ramach tej polityki jej zasady w tym przede wszystkim zrównoważony rozwój i przezorność. Zgodnie z zamierzeniem twórców rozporządzenia koncepcja przezorności (ostrożności) stanowi podstawę konstrukcyjną normy. Działania, których obowiązek podjęcia przewiduje rozporządzenie w duże mierze są nią kierowane.

O zależności pomiędzy rozporządzeniem REACH a koncepcją zrównoważonego rozwoju stanowi preambuła regulacji. Rozporządzenie REACH jest jednym ze środków, który zgodnie $\mathrm{z}$ „Odnowioną strategią zrównoważonego rozwoju” ma przyczyniać się do jego osiągnięcia. REACH jest środkiem, dzięki któremu ma zostać zrealizowany jeden z celów operacyjnych, które przewiduje strategia. Mowa tu o zdrowiu publicznym, które obok pozostały sześciu - do których należą: walka za zmianami klimatycznymi i pozyskiwanie czystej energii, zrównoważony transport, zrównoważona konsumpcja i produkcja, ochrona zasobów naturalnych i gospodarowanie nimi, integracja społeczna, demografia i migracja oraz wyzwania w zakresie globalnego ubóstwa i trwałego rozwoju stanowi jedno z głównych wyzwań „Odnowionej strategii”, których implementacja ma przyczynić się do osiągnięcia zrównoważonego rozwoju na obszarze Unii Europejskiej. „Odnowiona strategia”"18 zakłada, że przed rokiem 2020 sposób produkcji, przemieszczania i wykorzystywania substancji chemicznych, w tym pestycydów, powinien być tak zreformowany, aby nie stanowiły poważnego zagrożenia dla zdrowia ludzkiego i środowiska. Cel ten, zgodnie ze Strategią zostanie osiągnięty poprzez szybkie przyjęcie rozporządzenia w sprawie rejestracji, oceny, udzielania zezwoleń i stosowanych ograniczeń w zakresie chemikaliów (REACH). Przy czym naj-

18 Odnowiona strategia zrównoważonego rozwoju, Bruksela, 26 czerwca 2006, 10917/06, s. 15. 
ważniejsze jest, aby ostatecznie substancje wzbudzające szczególnie obawy zastąpione zostały odpowiednimi alternatywnymi substancjami lub technologiami.

Rozporządzenie REACH przewiduje, że dla osiągnięcia zrównoważonego rozwoju konieczny jest taki proces zbliżania przepisów dotyczących substancji który powinien zagwarantować wysoki poziom ochrony zdrowia ludzkiego i środowiska. Przy czym przepisy te powinny być stosowane w sposób niedyskryminacyjny zarówno $\mathrm{w}$ odniesieniu do substancji sprzedawanych na rynku wewnętrznym, jak i na rynku międzynarodowym, zgodnie z międzynarodowymi zobowiązaniami Unii Europejskiej ${ }^{19}$.

\section{ELEMENTY ROZPORZĄDZENIA REACH}

\subsection{REJESTRACJA}

Zgodnie z art. 6 rozporządzenia obowiązkiem rejestracji objęty jest każdy producent lub importer substancji, w jej postaci własnej lub jako składnika jednego lub większej liczby preparatów, w ilości co najmniej 1 tony rocznie. Dokumenty rejestracyjne przekładane są Europejskiej Agencji Chemikaliów. Obowiązek przedłożenia dokumentów rejestracyjnych Agencji, zgodnie z art. 7 rozporządzenia ciąży na każdym wytwórcy lub importerze wyrobów w odniesieniu do każdej substancji zawartej w tych wyrobach jeżeli substancja ta jest obecna w ilości stanowiącej łącznie ponad 1 tonę rocznie na wytwórcę lub importera oraz zamierzone jest uwolnienie substancji podczas normalnych lub racjonalnie przewidywalnych warunków stosowania. Szczegółowe dane, których obowiązek dostarczenia spoczywa na producencie obejmują dane identyfikujące producenta (producentów) lub importera (importerów), dane identyfikujące substancję, informacje dotyczące produkcji i zastoso-

19 Pkt 3 preambuły do rozporządzenia REACH. 
wań substancji (informacje te obejmują wszystkie zastosowania zidentyfikowane przez rejestrującego). Jeżeli rejestrujący uzna to za stosowne, informacje te mogą zawierać odpowiednie kategorie stosowania i narażenia; klasyfikację i oznakowanie substancji, wytyczne dotyczące bezpiecznego stosowania substancji propozycje przeprowadzenia badań, jeżeli zostały wymienione.

Podsumowując, rejestracja obejmuje wskazanie informacji na temat substancji (w tym ich klasyfikacji, właściwości fizycznych, zastosowania) badań na temat ich toksyczności, oceny ryzyka substancji, a co za tym idzie wskazania odpowiednich środków zarządzania ryzykiem. Rejestracja obejmuje pojedyncze substancje, ich grupy i grupy produktów chemicznych. Komplet danych jest wymagany, zgodnie z rozporządzeniem wówczas gdy istnieją przesłanki wskazujące, że substancja powinna być klasyfikowana jako niebezpieczna i jest stosowana w produktach konsumenckich lub handlu.

Proces rejestracji substancji wprowadzonych do obrotu na terenie UE w ilości co najmniej 1 tony odbywa się w oparciu o harmonogram, który przewiduje rozłożenie rejestracji substancji na 11 lat od daty wejścia w życie rozporządzenia REACH.

Termin rejestracji uzależniony jest ilości ton substancji wprowadzanych na rynek oraz od stopnia ich szkodliwości odpowiednio gdy roczny obrót przekracza 1000 ton termin rejestracji mijał w listopadzie 2010, dla substancji o rocznym obrocie od 100-1000 ton - 30 listopada 2013 r. oraz dla substancji o rocznym obrocie od 1-100 ton - 31 maja $2018^{20}$.

Jeżeli substancja nie zostanie zarejestrowana oznacza to, że nie może ona zostać wprowadzona do obrotu na rynku UE.

\subsection{OCENA}

Wymagania dotyczące realizacji rozporządzenia REACH rosną, wraz ilością wytwarzanych lub importowanych chemikaliów.

20 Informacja dostępna na stronie: http://www.pip.gov.pl/html/pl/doc/ reach_info.pdf, data wejścia 27.01.2014 r. 
Oceny substancji zgodnie z rozporządzeniem dokonują państwa członkowskie na podstawie informacji dostarczonych przez producentów. Kryteria oceny wskazane są przez Europejską Agencję Chemikaliów. Zgodnie z art. 14 rozporządzenia istnieje obowiązek przeprowadzenia oceny bezpieczeństwa chemicznego oraz sporządzenia raportu bezpieczeństwa chemicznego dla wszystkich substancji podlegających rejestracji, (o których stanowi rozdział pierwszy rozporządzenia) w ilości co najmniej 10 ton rocznie na jednego rejestrującego ${ }^{21}$. W przypadku braku realizacji przez producenta lub importera obowiązku dokonania oceny ryzyka, nie może on sprzedawać swoich produktów na rynkach Unii Europejskiej lub Europejskiego Obszaru Gospodarczego.

Ocena zgodnie z rozporządzeniem będzie dokonywana również w odniesieniu do substancji, które wzbudzają największe obawy co do ich negatywnego wpływu na środowisko i zdrowie człowieka. Ocena dokonywana jest na podstawie danych przedstawionych przez producenta pod względem ich kompletności, jakości oraz ewentualnej potrzeby podjęcia środków zapobiegawczych w celu uniknięcia przeprowadzenia badań na zwierzętach. Skutkiem przeprowadzonej oceny może stać się konieczność przeprowadzenia na wniosek Agencji Chemikaliów dodatkowych badań lub wprowadzenia ograniczeń w obrocie chemikaliami, jeżeli okaże się, że istnieje podejrzenie wystąpienia ryzyka negatywnego oddziaływania na życie lub zdrowie ludzi, które wywołane jest przez oceniane substancje ${ }^{22}$.

\subsection{AUTORYZACJA CZYLI PROCEDURA UZYSKIWANIA ZEZWOLEŃ}

W odniesieniu do substancji które wzbudzają szczególne obawy w zakresie możliwości ich negatywnego oddziaływania a więc substancji rakotwórczych, mutagennych i substancji, które wykazują rozrodcze efekty szkodliwe, ich producenci będą musieli ubiegać się o udzielenie zezwolenia na wprowadzenie

22 L. Kramer, EC Environmental Law, Sweet \& Maxwell 2011, s. 230. 
substancji na rynek unijny. Chcąc uzyskać zezwolenie producent powinien wykazać, że stosowanie tych produktów jest bezpieczne bądź też, że istnieje społeczno-gospodarcza potrzeba ich dalszego stosowania. Producent musi wykazać, że ryzyko, jakie mogą powodować substancje przez niego zgłaszane jest przez niego kontrolowane. Udzielanie zezwoleń nie należy już jednak do Europejskiej Agencji Chemikaliów ale do Komisji, która opiera swą decyzję na ustaleniach dokonanych przez Agencję.

\section{ZWIAZZKI ROZPORZĄDZENIA REACH Z ZASADĄ OSTROŻNOŚCI}

Zasada przezorności wywodzi się z dorobku prawa międzynarodowego. Po raz pierwszy w umowie międzynarodowej pojawiła się w Deklaracji przyjętej w wyniku Pierwszej Międzynarodowej Konferencji dotyczącej ochrony Morza Północnego w 1984 r. Najbardziej powszechne jej rozumienie znajduje się w Deklaracji z Rio de Janeiro w sprawie środowiska i rozwoju. Zgodnie z zasadą 15 zawartą w Deklaracji, „Wszystkie państwa powinny szeroko zastosować zapobiegawcze podejście w celu ochrony środowiska, mając na uwadze ich własne możliwości. Tam, gdzie występują zagrożenia poważnymi lub nieodwracalnymi zmianami, brak całkowitej naukowej pewności nie może być powodem opóźniania efektywnych działań, których realizacja prowadziłaby do degradacji środowiska"23. Pomimo treści zasady przezorności, jaką niesie Deklaracja oraz Komunikat Komisji Europejskiej, jak dotąd nie sformułowano powszechnie akceptowanej definicji tej reguły. Wielokrotnie znajduje ona swe miejsce w źródłach prawa międzynarodowego, jak również w porządkach krajowych, brak jednak wciąż jednolitej jej defi-

23 Deklaracja z Rio de Janeiro z 1992 r. w sprawie środowiska i rozwoju, źródło: M. M. Kenig-Witkowska, Międzynarodowe prawo środowiska, przepisy z wprowadzeniem, Warszawa 2009. 
nicji ${ }^{24}$. Mając powyższe na uwadze warto przychylić się do poglądu J. Zandera, że ważniejszy od sposobu jej definiowania jest zakres jej realizacji, a więc efekt, jaki wywiera na środki służące ochronie środowiska ${ }^{25}$.

Zgodnie z Komunikatem Komisji Europejskiej w sprawie zasady ostrożności ${ }^{26}$ jest ona stosowana wówczas gdy zidentyfikowane zostaną potencjalnie negatywne skutki „wynikających ze zjawiska, produktu lub procedury” oraz „naukowej oceny ryzyka, która z powodu niewystarczających danych, ich niejednoznacznego lub nieprecyzyjnego charakteru, nie pozwala na określenie z wystarczającą pewnością kwestii ryzyka".

$\mathrm{Na}$ zasadę przezorności składają się 4 elementy. Pierwszy z nich odzwierciedla związek zasady ostrożności z zasadą prewencji (niekiedy zasady traktowane są jako jedna reguła). Zgodnie z nim działania o prewencyjnym charakterze powinny być podejmowane w sytuacji niepewności - a więc przy braku wystarczających dowodów naukowych co do możliwości wystąpienia szkody w środowisku. Zasada przezorności jest więc stosowana, gdy istnieją uzasadnione podstawy do obaw, że mogą wystąpić potencjalnie niebezpieczne skutki dla środowiska, ludzi, zwierząt lub roślin w wyniku zastosowania niewłaściwego poziomu ochrony ${ }^{27}$. Po drugie, zasada przezorności przenosi

24 P. Sandin, A Paradox Out of Context: Harris and Holm on the Precautionary Principle, „Cambridge Quarterly of Healthcare Ethics” 2006, nr 15, s. 175; Przykładami jej obecności może być również Protokół Montrealski dotyczących substancji zubażających warstwę ozonową czy Protokół Kartageński w sprawie ochrony bioróżnorodności.

25 J. Zander, The Application of the Precautionary Principle in Practice, Comparative Dimension, Cambridge University Press, Wielka Brytania, 2010, s. 26.

26 Komisja Europejska, Communication from the Commission on the Precautionary Principle, COM(2000) Final, European Commission, Brussels, dostępne na: http://eur-lex.europa.eu/LexUriServ/LexUriServ.do?uri=COM:2000:0001:FIN:EN:PDF, s. 10, data wejścia 26.01.2014; Na gruncie prawa Unii Europejskiej, w odniesieniu do koncepcji przezorności w tekście zastosowane zostanie pojęcie „zasady przezorności”, wynika ono bowiem z tłumaczenia Traktatu o Funkcjonowaniu Unii Europejskiej oraz z tłumaczeń dokumentów dotyczących tej koncepcji.

27 Ibidem, s. 10. 
niejako ciężar dowodu lub odpowiedzialność na dokonujących działania, które potencjalnie mogłyby mieć szkodliwy wpływ na środowisko. Zgodnie z zasadą przezorności należy również dokonać oceny, czy nie istnieje możliwość wprowadzenia rozwiązań alternatywnych ${ }^{28}$. Ostatnią czwartą cechą konstruującą definicję zasady przezorności jest konieczność zwiększenia udziału społeczeństwa w podejmowaniu decyzji ${ }^{29}$.

W przypadku przywołania zasady ostrożności poza konkretnymi zasadami stosuje się też pięć zasad ogólnych. Są one następujące: podjęte środki muszą być proporcjonalne do docelowego poziomu ochrony (zasada proporcjonalności), środków nie należy stosować w sposób dyskryminacyjny (zasada niedyskryminacji), środki muszą być zgodne ze środkami przyjętymi w sytuacjach podobnych lub opierających się na podobnym podejściu, (zasada spójności), potencjalne zalety i wady danego działania lub braku działania muszą zostać poddane analizie (analiza kosztów i korzyści) w świetle rozwoju nauki ${ }^{30}$.

Podejście Komisji Europejskiej do zasady ostrożności wyznacza dwa różne aspekty tej zasady, tj. warunkuje decyzję polityczną - czy podjąć określone działania czy też ich zaniechać oraz jakie środki będą właściwe jeżeli podjęte zostaną działania na podstawie zasady ostrożności ${ }^{31}$.

W wydanej przez Komisję Europejką „Białej Księdze” dotyczącej zmiany sposobu zarządzania chemikaliami ${ }^{32}$ zasada przezorności wskazywana jest jako podstawa do osiągnięcia wysokiego stopnia ochrony zdrowia ludzkiego i środowiska obecnych i przyszłych pokoleń przy równoczesnym zapewnieniu

28 S. Foss Hansen, L. Carlsen, J. A. Tickner, Chemicals regulation and precaution: does REACH really incorporate the precautionary principle, „Environmental Science \& Policy" 2007, nr 10, s. 395.

29 http://europa.eu/legislation_summaries/consumers/consumer_safety/132042_pl.htm, data wejścia: 18.12.2013

30 Informacja dostępna na: http://europa.eu/legislation_summaries/consumers/consumer_safety/132042_pl.htm, data wejścia : 18.12.2013.

31 Ibidem.

32 The White Paper on Strategy for a future chemicals Policy. COM (2001) 88 Final, Komisja Europejska, Bruksela, 27.2.2001, dostępne na: http://eur lex.europa.eu/LexUriServ/LexUriServ.do?uri=COM:2001:0088:FIN:EN:PDF; data wejścia 8.12.2013 r. 
efektywnego funkcjonowania wspólnego rynku chemikaliów (przemysłu chemicznego) nie naruszając przy tym reguł konkurencji. Zasada przezorności, zgodnie z treścią „Białej Księgi” stosowana jest wówczas, gdy pomimo istnienia wiarygodnych dowodów naukowych co do szkodliwego wpływu substancji na zdrowie człowieka i środowisko naturalne wciąż nie ma naukowej pewności co do charakteru i wielkości szkód, które może ona potencjalnie wywołać. Zasada przezorności w takiej sytuacji staje się podstawą dla podjęcia decyzji, których celem jest zapobieżenie szkodom w środowisku i zdrowiu ludzkim ${ }^{33}$.

Zagadnienie zakresu obecności zasady przezorności w rozporządzeniu REACH stanowiło przedmiot rozważań twórców rozporządzenia. Sposób patrzenia na obecność zasady przezorności w rozporządzeniu REACH zależy od tego, jak postrzegane są podstawowe cele regulacji, do których należy poziom ochrony zdrowia ludzkiego oraz ochrony środowiska w odniesieniu do wprowadzanych innowacji w produkcji, służących osiągnięciu celów rozporządzenia.

$\mathrm{Z}$ zasada tą niewątpliwie pozostaje $\mathrm{w}$ zgodzie przerzucenie odpowiedzialności za ocenę szkodliwości substancji z władz publicznych na producentów czy też wprowadzona przez rozporządzenie konieczność poszukiwanie rozwiązań alternatywnych. Przerzucenie odpowiedzialności w ramach rozporządzenia REACH polega na powierzeniu producentom i importerom obowiązku rejestracji i obowiązku ubiegania się o udzielanie zezwoleń na wprowadzenie chemikaliów do obrotu, udzielając informacji dotyczących substancji chemicznych i ich toksyczności. Ich obowiązkiem jest również przekazywanie informacji na temat posiadanych nowych wiadomości dotyczących zagrożenia, jakie dla zdrowia i środowiska mogą powodować wytwarzane przez nich substancje. Przerzucenie odpowiedzialności za dostarczenie informacji na wytwórcę substancji stanowi wyraz zasady przezorności ponieważ zgodnie z zasadą, prawdopodobieństwo popełnienia błędu $\mathrm{w}$ trakcie podejmowania decyzji w oparciu o tę zasadę powinno być minimalizowane. Podmiotem zaś, który co do zasady dysponuje najszerszą wiedzą na

33 Ibidem. 
temat substancji podlegających rozporządzeniu jest ich producent. Problem pojawia się jednak wówczas, gdy dane przez niego wskazywane są nieprawdziwe. Nie można wówczas mówić o efektywnej realizacji zasady przezorności przez rozporządzenie. Kwestia przerzucenia ciężaru odpowiedzialności jest bez wątpienia wyrazem realizacji zasady ostrożności, jakkolwiek, na co zwracają uwagę S. Foss Hansen, L. Carlsen, J. A. Tickner ${ }^{34}$, zgodnie z Komunikatem w sprawie zasady ostrożności nie jest warunkiem koniecznym jej realizacji. Z pewnością, jak wskazują, nie jest wystarczające, by zapewnić wysoki poziom ochrony zdrowia i środowiska naturalnego. Zauważyć równocześnie należy, co podkreśla A. Longomasi, że przerzucenie odpowiedzialności za dostarczenie informacji dotyczących substancji chemicznych na ich producentów może prowadzić do arbitralnej decyzji dotyczącej wyłączenia z rynku tych substancji. Wytwórcy bowiem nie są w stanie udowodnić, że ich produkt w każdym przypadku jest całkowicie bezpieczny. Zastosowanie zasady ostrożności daje więc w tej sytuacji dużą swobodę decyzji, ponadto powodować może zniechęcenie do wprowadzania rozwiązań innowacyjnych ${ }^{35}$.

Problematyka udzielania informacji przez producenta wiąże się z kwestią przejrzystości podejmowanych działań - decyzji. Cecha ta wpływa również na możliwość mówienia o obecności zasady przezorności w rozporządzeniu REACH. Ponadto obowiązkiem producenta jest wskazanie, że substancje chemiczne są odpowiednio kontrolowane oraz, że korzyści społeczno-ekonomiczne wynikające $\mathrm{z}$ ich produkcji przewyższają stopień ryzyka stwarzany przez te substancje ${ }^{36}$.

W kontekście zasady przezorności można rozpatrywać także autoryzację będącą jednym z elementów konstruujących rozporządzenie REACH.

Przedmiotem autoryzacji zgodnie z rozporządzeniem są substancje rakotwórcze, mutagenne, toksyczne jak również

34 S. Foss Hansen, L. Carlsen, J. A. Tickner, op. cit., s. 398.

35 A. Logomasini, Europe's global REACH: costly for the world; suicidal for Europe, Institute Hayek, Bruksela, listopad 2005, s. 4.

36 Ibidem. 
bardzo trwałe i wykazujące wysoką zdolność do bioakumulacji. Jak zauważa M. Karlsson, takie ujęcie substancji zwiększa ilość substancji niebezpiecznych uważanych za cel dalszego postępowania (zarządzania tymi substancjami), z drugiej zaś substancjom tym w procedurze autoryzacji przyznawane jest zezwolenie na ich wprowadzenie na rynek, gdy każda z tych substancji jest odpowiednio kontrolowana, a ich obrót korzystny ze społeczno-gospodarczego punktu widzenia, korzyści te zaś przewyższają ryzyko, które może zostać przez substancje wywoływane. Na co wskazuje autor, istnieje jednak trudność w dokonaniu właściwej analizy skutków społeczno-gospodarczych, które wywoływać mogą substancje. Polega ona na tym, że skonfrontować ze sobą należy koszty regulacyjne, ponoszone w krótkiej perspektywie czasowej z korzyściami, jakie regulacja może przynieść zdrowiu ludzkiemu i środowisku w odleglejszej perspektywie. Biorąc pod uwagę wysoki stopień niepewności, określenie wskazanych skutków jest niemalże niemożliwe. Oznacza to, że koncepcja autoryzacji, o której stanowi rozporządzenie, jest nie do pogodzenia z zasadą przezorności ${ }^{37}$.

Z drugiej zaś strony obecność zasady przezorności w procesie autoryzacji może powodować podejmowanie przez państwa członkowskie i EU decyzji o autorytarnym charakterze. Państwa członkowskie mając bowiem możliwość zakazania obrotu substancjami chemicznymi, w sytuacji gdy nie dysponują jeszcze pełnymi danymi co do ich szkodliwości - na to pozwala im zasada ostrożności. Zgodnie ze stanowiskiem Komisji Europejskiej istnieje możliwość wyłączenia substancji z obrotu, gdy czas oczekiwania na wyniki badań naukowych jej dotyczących jest zbyt długi oraz gdy dostępne dane naukowe nie pozwalają na ustalenie poziomu ryzyka z wystarczają-

37 M. Karlsson, Science and norms in policies for sustainable development: Assessing and managing risks of chemical substances and genetically modified organisms in the European Union, „Regulatory Toxicology and Pharmacology” 2006, nr 44, s. 53. 
cą pewnością ${ }^{38}$. Jak zauważa A. Longomasi, takie rozumienie działań podejmowanych $\mathrm{w}$ oparciu o zasadę ostrożności powoduje, że decyzja o wyłączeniu pewnych substancji z rynku ma wyłącznie polityczny charakter ${ }^{39}$.

Można wskazać na dalsze zależności pomiędzy zasadą ostrożności a problematyką zarządzania chemikaliami. Należy do nich oddziaływanie substancji toksycznych na zdrowie ludzi i środowisko zarówno w przeszłości, jak i w przyszłości, również przy braku wiedzy na temat szkodliwości niektórych z substancji. Należy wskazać także obowiązki władz publicznych, które zanim podejmą działania zapobiegające muszą wykazać negatywny wpływ substancji chemicznych na zdrowie człowieka i na środowisko. Problemem jest również brak systemu, który sprzyjałby rozwojowi innowacji, tak ażeby powstające chemikalia były bezpieczniejsze dla środowiska i zdrowia ludzkiego ${ }^{40}$.

Zasada przezorności jest środkiem służącym zarządzaniu ryzykiem. Ryzyko definiowane jest jako zależność (funkcja) zagrożenia i narażenia na jego wystąpienie. Zasada przezorności ma zastosowanie zawsze wówczas, gdy ryzyko osiąga nieakceptowany poziom. Dokonanie oceny ryzyka w odniesieniu do substancji chemicznych jest o tyle trudne, że zakres substancji, które mogą oddziaływać na zdrowie ludzkie i środowisko, jest bardzo szeroki, substancje te zaś są o różnym stopniu toksyczności. Ponadto jesteśmy narażeni na oddziaływanie substancji pochodzących z wielu źródeł - środowisko w którym przebywamy w domu i w pracy. To wszystko utrudnia określenie stopnia ryzyka - ze względu na wielość źródeł, z których ono pochodzi ${ }^{41}$. Taka sytuacja utrudnia sposób zarządzania chemikaliami - z uwagi na ryzyko, którego źródłem

38 European Commission, Questions and Answers on REACH, Part II, Bruksela: Komisja Europejska, Listopad, 2004, http://europa.eu.int/comm/enterprise/reach/docs/reach/qa_reach_part 2_2004_11_22_en.pdf. podaję za Lo-

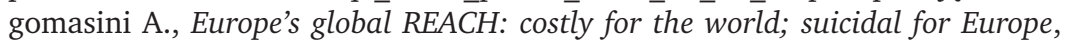
op. cit.

\footnotetext{
39 Ibidem, s. 10.

40 S. Foss Hansen, L. Carlsen, J. A. Tickner, op. cit., s. 396

41 J. Lee, A. Brandt Pedersen, M. Thomson, op. cit., s. 105.
} 
może być wiele czynników. Wyzwaniem w zakresie regulacji dotyczącej chemikaliów jest więc koncepcja zintegrowanej oceny ryzyka oraz zarządzanie nim. Zintegrowana ocena ryzyka jest środkiem służącym skutecznemu radzeniu sobie ze skumulowanymi zagrożeniami pochodzącymi z wielu źródeł jakie niosą chemikalia.

Rozporządzenie REACH przewiduje, że ocena ryzyka dotycząca produkcji chemikaliów i ich stosowania musi zostać przeprowadzona i udokumentowana przed ich wprowadzeniem do obrotu.

\section{PODSUMOWANIE}

Podsumowując problematykę zależności pomiędzy rozporządzeniem REACH a zasadą należy podkreślić, że Komisja Europejska uznaje, że rozporządzenie REACH opiera się na zasadzie ostrożności. W literaturze przedmiotu podaje się w wątpliwość zależność pomiędzy ideą rozporządzenia REACH opierającego się na rejestracji, ocenie i autoryzacji a zasadą ostrożności. Tym, co również budzi wątpliwość, jest to, czy wprowadzone przez rozporządzenie REACH środki faktycznie tworzą bezpieczniejsze rozwiązania alternatywne - czego wymaga zasada ostrożności ${ }^{42}$. Analizując rozporządzenie, można odnaleźć $\mathrm{w}$ nim również elementy niepozostające w zgodzie z zasadą ostrożności. Może to wynikać z trudności w realizacji samej zasady i wątpliwości, jakie rodzą się w procesie jej stosowania. S. Foss Hansen, L. Carlsen, J. A. Tickner ${ }^{43}$ wskazują na problemy, jakie wywołuje stosowanie zasady ostrożności. Ich zdaniem w Komunikacie do-

42 N.I. Meyer, Kemien ude af kontrol, Information 2004, marzec (3) s. 8 (wersja w j. duńskim); L. Koch, N. Ashford, Rethinking the role of information in chemicals policy: implications for TSCA and REACH, „Journal of Cleaner Production" 2006, nr 14, s. 31-46; podaję za: S. Foss Hansen, L. Carlsen, J. A. Tickner, op. cit., s. 395.

43 Ibidem, s. 398. 
tyczącym omawianej zasady znajdują się pewne braki, które powodują trudność w realizacji zasady. Komunikat w sprawie zasady ostrożności, jak wskazują:

- „nie daje jasnej odpowiedzi, kiedy zasada ostrożności powinna być stosowana, używa nieprecyzyjnych sformułowań jak np. „niejednoznaczność i niejasność danych naukowych" czy też „uzasadnione powody do obaw”, „wybrany poziom ochrony”;

- definiuje niepewność naukową jako wynik metody naukowej istniejących danych pomijając fakt, że najbardziej istotne wątpliwości przy rozpatrywaniu zasady ostrożności i ryzyka i wynikają z kontrowersji z istniejących danych nieokreśloności i niewiedzy;

- Komisja dokonuje rozróżnienia pomiędzy oceną ryzyka traktując ją ściśle w kategoriach naukowych a zarządzaniem ryzykiem uznając je tylko za decyzję o politycznym charakterze nie zauważając, że w istocie jest ono trudne do przeprowadzenia. Przede wszystkim z uwagi na fakt, że istnieje wiele warunków wpływających na dokonywanie oceny ryzyka a co za tym idzie na podjęcie decyzji co do zastosowania zasady"44.

Tym, na co wskazuje się w literaturze przedmiotu na pozostające $\mathrm{w}$ sprzeczności $\mathrm{z}$ założeniami rozporządzenia REACH, jest przede wszystkim brak jasności co do tego, do jakiego stopnia pierwszy z elementów tworzących zasadę ostrożności, a więc podejmowanie działań zapobiegawczych przy posiadaniu niepełnych danych naukowych jest realizowane. Podejmowanie decyzji w oparciu o zasadę ostrożności powodować może, przy częstym braku całkowitej pewności co do właściwości substancji, że będą one wycofywane z rynku na podstawie tylko politycznej decyzji. Zbyt rygorystyczne wymogi stawiane przez rozporządzenie również nie pozwalają na realizację tej zasady ${ }^{45}$.

44 Ibidem.

45 M. Karlsson, op. cit., s. 49-56. 


\section{BIBLIOGRAFIA}

Assmuth T., Hildén M., Craye M., Beyond REACH: Roadblocks and shortcuts en route to integrated risk assessment and management of chemicals, „Science of the Total Environment” 2010, nr 408.

Bester K., Scholes L., Wahlberg C.S., McArdell C., Sources and mass flows of xenobiotics in urban water cycles - an overview on current knowledge and data gaps, „Water Air \& Soil Pollution” 2008, nr 8.

Fromberg A., Cleemann M., Carlsen L., Review on persistent organic pollutants in the environment of Greenland and Faroe Islands, „Chemosphere” 1999, nr 38.

Kramer L., EC Environmental Law, Sweet \& Maxwell 2011.

Kenig-Witkowska M. M., Międzynarodowe prawo środowiska, przepisy z wprowadzeniem, Warszawa 2009.

Karlsson M., Science and norms in policies for sustainable development: Assessing and managing risks of chemical substances and genetically modified organisms in the European Union, „Regulatory Toxicology and Pharmacology" 2006, nr 44.

Koch L., Ashford N., Rethinking the role of information in chemicals policy: implications for TSCA and REACH, „Journal of Cleaner Production" 2006, nr 14.

Lee J., Brandt Pedersen A., Thomson M., Framework for combining REACH and national regulations to obtain equal protection levels of human health and the environment in different countries, Comparative study of Denmark and Korea, „Journal of Environmental Management" 2013, nr 125.

van Leeuwen C.J., Vermeire T. G., (red.), Risk Assessment of Chemicals: An Introduction, Springer, Holandia 2007.

Loewenberg S., US chemical companies leave their mark on EU law, „Lancet” 2006, nr 367 (9510).

Logomasini A., Europe's global REACH: costly for the world; suicidal for Europe, Institute Hayek, Bruksela, listopad 2005.

Pesendorfer D., EU environmental policy under pressure: chemicals policy change between antagonistic goals?, „Environmental Politics” 2006, nr15 (1).

Rockström J., A safe operating space for humanity, „Nature” 2009, nr 461.

Sandin P., A Paradox Out of Context: Harris and Holm on the Precautionary Principle, „Cambridge Quarterly of Healthcare Ethics” 2006, nr 15. 
Foss Hansen S., Carlsen L., Tickner J. A., Chemicals regulation and precaution: does REACH really incorporate the precautionary principle, „Environmental Science \& Policy” 2007, nr 10.

Zander J., The Application of the Precautionary Principle in Practice, Comparative Dimension, Cambridge University Press, Wielka Brytania 2010.

Kontakt e-mail:

jkielin@alk.edu.pl 